\title{
Ecological, Biological and Genetic Adaptation to Xeric Habitats of Salamandra infraimmaculata on the Southern Border of Its Distribution
}

\author{
Gad Degani ${ }^{1,2}$ \\ ${ }^{1}$ Faculty of Science and Technology, Tel-Hai Academic College, Kiryat Shmona, Israel \\ ${ }^{2}$ MIGAL-Galilee Technology Center, Kiryat Shmona, Israel \\ Email:gad@migal.org.il
}

How to cite this paper: Degani, G. (2017) Ecological, Biological and Genetic Adaptation to Xeric Habitats of Salamandra infraimmaculata on the Southern Border of Its Distribution. Open Journal of Animal Sciences, 7, 70-92.

http://dx.doi.org/10.4236/ojas.2017.71007

Received: December 30, 2016

Accepted: January 23, 2017

Published: January 26, 2017

Copyright $\odot 2017$ by authors and Scientific Research Publishing Inc. This work is licensed under the Creative Commons Attribution International License (CC BY 4.0).

http://creativecommons.org/licenses/by/4.0/

\begin{abstract}
In the present mini-review, published and unpublished data that have been collected for more than 40 years on the adaption of Salamandra infraimmaculata to semi-arid environments on the southern border of its distribution are presented. The contribution of the present paper is in building a model based on comparing moist habitats with predictable and relatively constant conditions to semi-arid habitats with relatively dry conditions. Based on these parameters, the model suggests adaptation to semi-arid habitats. More specifically, this model is based on the morphology, biology, behavior, life cycle and physiology of $S$. infraimmaculata adaptation. By considering these many parameters, one hypothesis was raised and was supported. The adaptation to and selection of semi-arid habitats depend mainly on the terrestrial phase and very little on the aquatic phases. In all of the semi-arid habitats, there are various breeding places where the larvae can grow and complete metamorphosis. The molecular genetic variation among the various areas supports our hypothesis, and the difference in the moist habitats is greater than in the semi-arid environments.
\end{abstract}

\section{Keywords}

Adaptation, Distribution, Genetic, Life Cycle, Salamandra infraimmaculata

\section{Introduction}

One aspect of ecology defines, among the other things, a branch of biology that deals with the relationships and interactions between organisms and their environment. In order to explain the adaption of organisms to a habitat, as many as possible biological parameters that are important to these characteristics must be studied. The Salamandridae family, comprising 16 genera and 66 recognized species, represents one of the 
most diverse groups of extant salamanders. Salamandrids have the largest geographic distribution of any salamander family, extending across the Holarctic continents of Asia, Europe and North America, with a small and recent expansion into North Africa [1]. Many aspects of S. infraimmaculata have been studied over the past 40 years on the southern border of its distribution [2]. Its adaption to various habitats and areas, including at extreme conditions on the southern border of its distribution, was examined. The present paper tries to suggest a model of adaptation to xeric habitats of $S$. infraimmaculata based on published (mini-review) and unpublished data by comparing characteristics from the biology, ecology, behavior and physiology of salamanders from different areas and environmental conditions. The objective of the present paper is to discuss various parameters affecting the adaptation of $S$. infraimmaculata to relatively dry conditions by comparing different habitats and suggesting a model to describe this adaptation.

\section{Distributions}

Salamandra infraimmaculata is present in the southeastern and eastern parts of Anatolia, Turkey, northwestern Iran, northern Iraq, Lebanon and northern Israel. Many aspects of S. infraimmaculata, some of which have been described in detail, have been studied over the past 40 years at the southern border of its distribution [2]. Based on the sequence analysis of the mitochondrial D-loop region and geological dates, Steinfartz [3] suggested that five major monophyletic groups exist in Europe ( $S$. salamandra, $S$. infraimmaculata, $S$. corsica, $S$. atraand $S$. lanzai), one $S$. algira is located in Africa [4], and the salamanders in Israel belong to $S$. infraimmaculata. The distribution of $S$. infraimmaculata in the Middle East is presented in Figure 1. In Iran, it is found in an arid sparse cork forest area. In Turkey and Lebanon, it has been found to inhabit damp forests and groves in mountainous or hilly regions, and shelter under leaves, roots or stones not far from water [2] [5] [6] [7] [8]. The populations of $S$. infraimmaculata found in Israel are located in breeding sites in different and isolated sub-regions within relatively short geographical distances: 1) Mount Hermon; 2) Tel Dan; 3) Naftali Mountains; 4) Upper Galilee; 5) Western Galilee [2] [5] [9]-[19]; 6) Lower Galilee [20]; and 7) Mount Carmel [7] [21] [22] (Figure 1).

\section{Different Habitats}

On the southern border of $S$. infraimmaculata distribution, as for many other amphibians, the habitats include two main components - terrestrial habitats and aquatics habitats, where the salamanders can complete their life cycle. During extensive studies carried out on $S$. infraimmaculata at the extreme conditions, various terrestrial habitats in the areas of the breeding places (Table 1) were described [2] [5] [21] [22]. Figure 2 presents various terrestrial habitats of $S$. infraimmaculata. $S$. infraimmaculata live in a number of different areas in Israel on the southern border of its distribution in diverse habitats (Figure 1 and Figure 2). They are found mainly at $340-760 \mathrm{~m}$ above sea level (ASL) (Table 1). Only the Tel Dan population is significantly lower at $190 \mathrm{~m}$, where the environmental conditions of this habitat differ from the others. The Upper Carmel is a complex habitat, formed by two vaulted ridges, with notable karst features. The upper ridge consists of Kanoman chalk, with a general height of $500 \mathrm{~m}$, reaching its maximum 


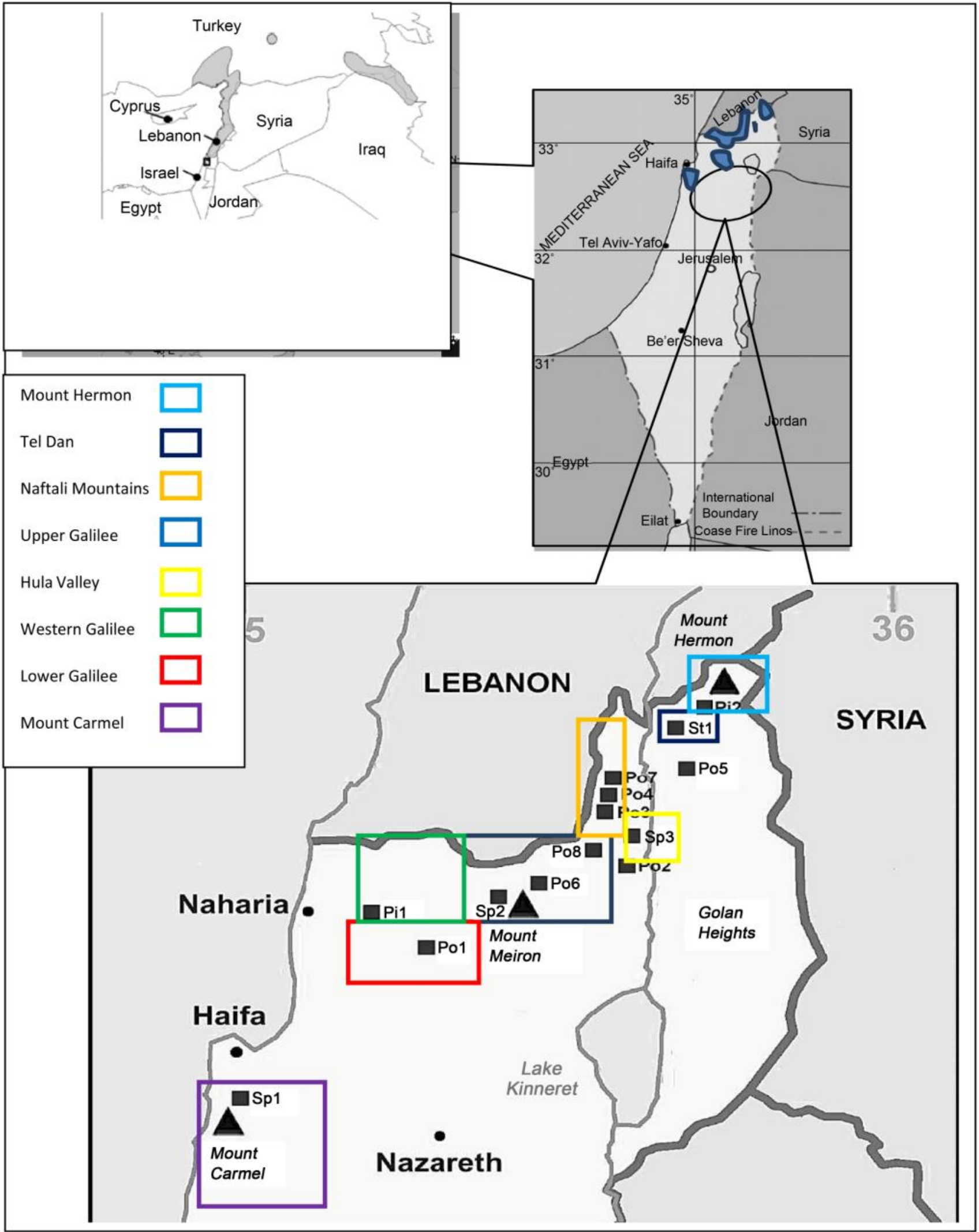

Figure 1. Map of various regions in Israel colonized by Salamandra infraimmaculata. Some breeding places: St1-Tel Dan Springs: Sp1-Balad, Sp2-Humema and Sp3-Navoraya. Pools: Po1-Manof, Po2-Kash, Po3-Dovev, Po4-Matityahu, Po5-Lehavot, Po6-Sasa, Po7-Fara and Po8-Raihaniya. Rock pool holes (pits): Pi1-Maalot and Pi2-Nimrod. 

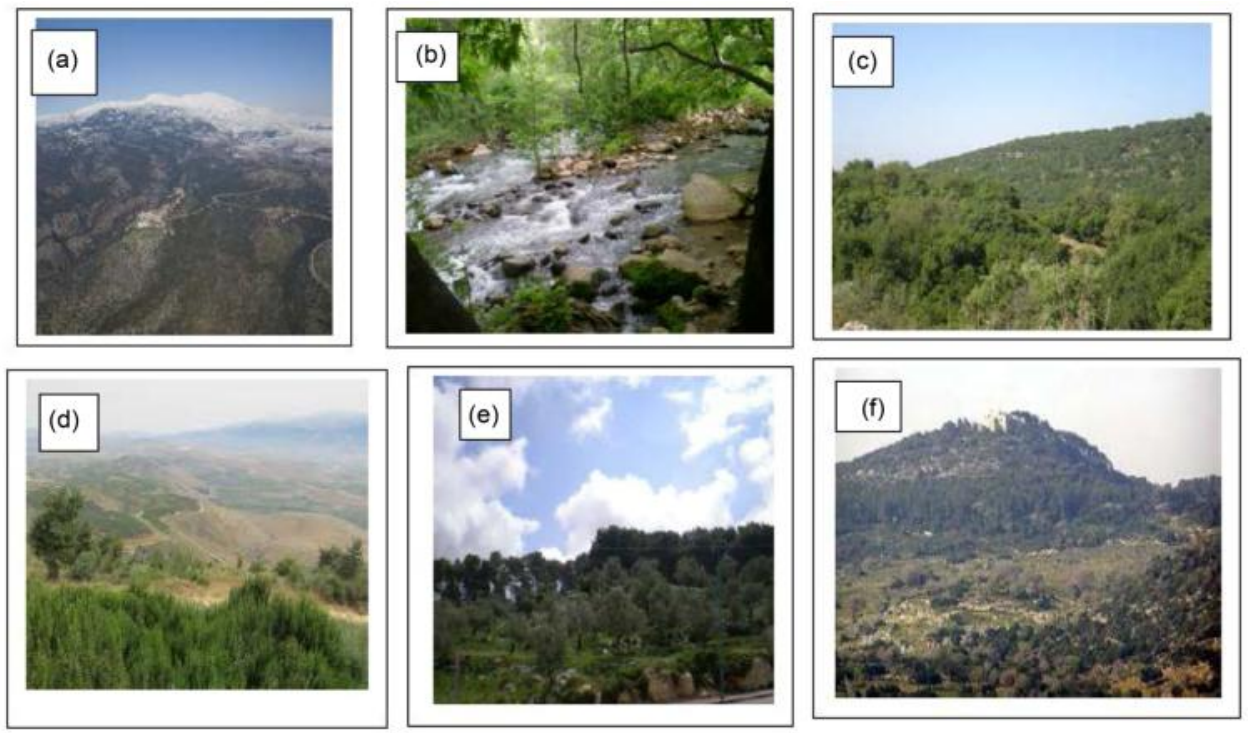

Figure 2. Various habitat sites of Salamandra infraimmaculata: (a). Mount Hermon; (b). Tel Dan Spring area; (c). Mount Meron, Upper Galilee; (d). Lower Galilee; (e). Western Galilee; (f). Mount Carmel.

Table 1. Characteristics of habitats in which Salamandra infraimmaculat larvae were found.

\begin{tabular}{ccccc}
\hline Label & Name & Type & Location & Height (m.a.s.1.) \\
\hline Sp1 & Balad & Spring & Carmel & 446 \\
St2 & Beit Oren & Stream & Carmel & 400 \\
Po2 & Damun & Pond & Carmel & 900 \\
Sp2 & Humema & Spring & Upper Galilee & 900 \\
Sp3 & Navoraya & Spring & Hula Valley & 663 \\
St1 & Tel Dan & Stream & Hula Valley & 190 \\
Pi1 & Maalot & Rock pool hole & Western Galilee & 596 \\
Pi2 & Nimrod & Rock pool hole & Mount Hermon & 760 \\
Po1 & Manof & Pool & Lower Galilee & 340 \\
Po3 & Dovev & Pool & Upper Galilee & 765 \\
Po6 & Sasa & Pool & Upper Galilee & 810 \\
Po7 & Fara & Pool & Naftali Mountains & 676 \\
\hline
\end{tabular}

of $548 \mathrm{~m}$ near Ussefiya; the second, running parallel to the first, consists of chalk and marl of the Lower Kanoman. This ridge runs from Tirat Hacarmel via Beit Oren to Daliat el Carmel, and is crossed by brooks, which carry rainfall down from the watershed; it is $450 \mathrm{~m}$ high, with a $497-\mathrm{m}$ peak at Mount Shekef. As a result of its proximity to the sea and the steepness of its seaward slope, the area receives rainfall comparable with that of the Upper Galilee: upward of $800 \mathrm{~mm}$ annually. The natural flora, which have been preserved over large parts of the range, consist of typical Mediterranean scrub. Communities of Quercus calliprinos and Pistacia palaestina mingle with communities of Genista fasselata and Pinus halepensis, the former predominating at Kfar Damun and the latter at Beit Oren. 
The salamander population in this area is concentrated around pools and springs, as in the Galilee region. Plentiful rainfall acting on the local chalk has given rise to a profusion of caves, holes and other settings for standing and running water. These are the water sources in which salamander larvae are found: winter pools, ponds, springs and streams. Some of the winter pools dry up in summer, and many of the other sources are exploited by man, including reservoirs cut into the rock, which are in use mainly in the summer. As a result of human activity, many of the springs and streams that once ran all year round are now dry in summer or polluted. The dense scrub and rocky terrain form a habitat that provides the salamander with numerous hiding places. The Tel Dan Nature Reserve is in the north-eastern part of the country; it lies among hills and is bounded by mountains to the north, but is itself only $180 \mathrm{~m}$ above sea level. The area as a whole is characterized by numerous spring-fed streams and running water, and is the only such area in Israel. The Nature Reserve is full of such brooks, which are spring-fed and run all year round, giving rise to the development of rich flora. Most of these brooks are shallow (usually $5-10 \mathrm{~cm}$ ) (Figure 2(b)). This constant presence of water and dense growth has created an optimal and stable environment for wildlife; flora include northern species such as Farxinus syriaca, and Paliurus spina-christi, as well as species more typical of the Mediterranean region such as Laurus nobilis, Rhamnus alaternus, Quercus ithaburensis and Styrax officinalis. This habitat remains constant throughout the year and is totally different from those in Mount Hermon, Upper Galilee (Figure 2(c)), Mount Meron, Lower Galilee (Figure 2(d)), Western Galilee (Figure 2(e)) and Mount Carmel (Figure 2(f)).

\section{Morphological Variations of Terrestrial Salamanders from Variation in Various Habitats}

The morphological parameters of salamanders have been studied in detail in Europe [2] [23]. A comparison between morphological parameters of Salamandra infraimmaculata in Israel at the southern border of its distribution was made between several populations in different areas: Tel Dan, Upper Galilee (Mount Meron), Western Galilee, and Mount Carmel [24] (Figure 1 and Figure 2). The body size of the salamanders from the Tel Dan population was significantly smaller than that of salamanders from the other areas. No difference was found in mean body measurements, and standard deviation calculated as described in [24] covered the mean between the three areas (Upper Galilee, Western Galilee and Mount Carmel) where the habitats are similar (Figure 3). More than $400 \mathrm{~S}$. infraimmaculata were measured in four different areas, and the color pattern of the bag spots were one line, two line and scattered at all localities (Figure 4). In Mount Carmel and Upper Galilee, the scattered pattern was higher, $63 \%$ and 59\% respectively, compared to Tel Dan and Western Galilee, which was 38\% and 18\%, respectively (Figure 4). However, no differences were found in spots in the various areas. In all of the populations, most of the salamanders had four spots on the head (Figure 5 ), which was the highest of the other patterns in all of the areas (1,2,3 or 5); the lowest pattern was 59\% in Tel Dan salamanders, and the highest was $86 \%$ in Mount Carmel salamanders (Figure 5). Most salamanders from all of the localities are on the ventral black side (Figure 6), about $90 \%$. In a small number of salamanders, a spot was found 

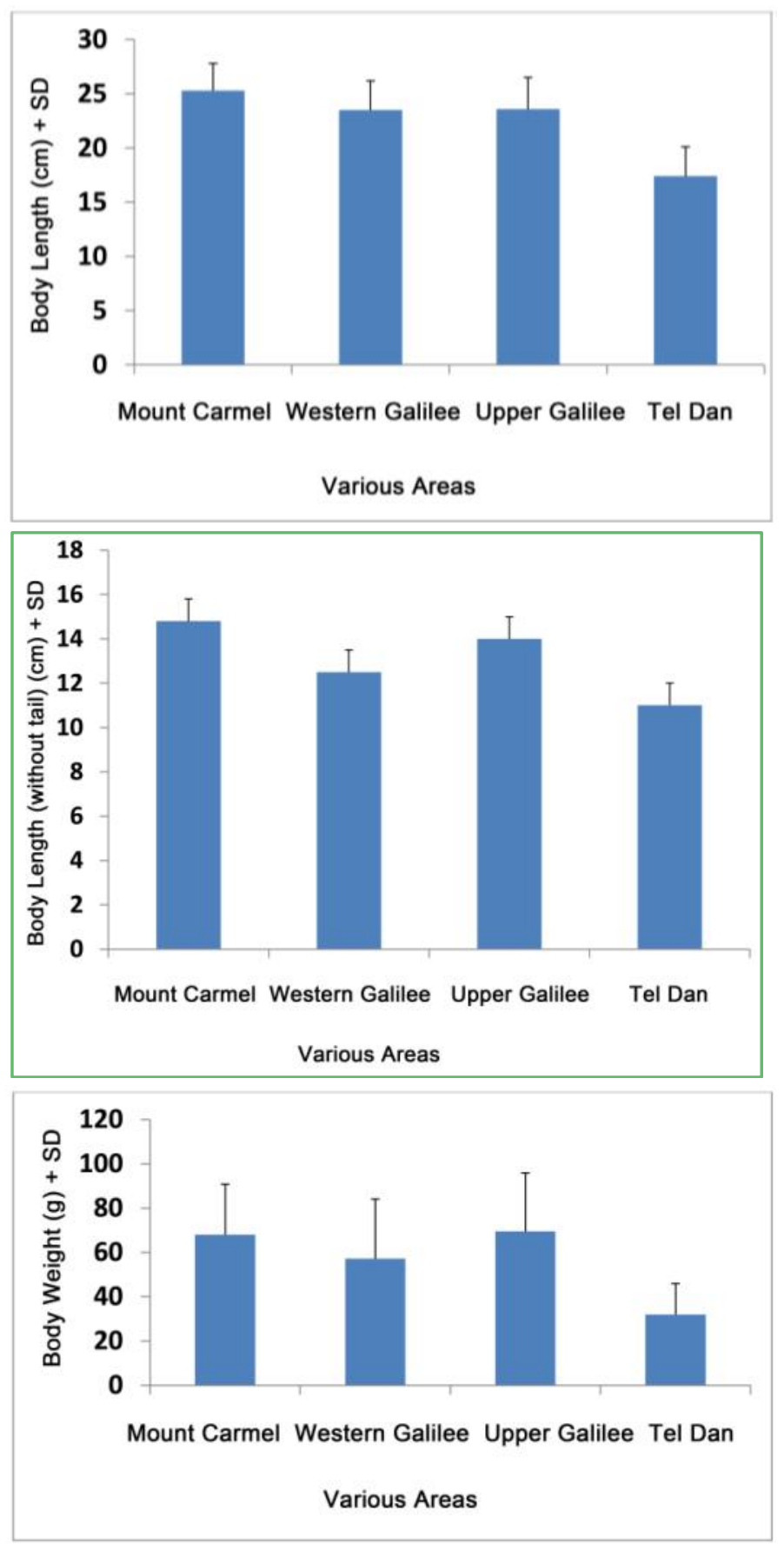

Figure 3. The measurements of salamanders from various areas.

on the jaw and the ventral side (Figure 6).

\section{Molecular Genetic Variations in Various Areas of S. infraimmaculata in Israel}

The genetic consequences of habitat fragmentation are an important component of population extinction risk assessment for threatened and endangered species. Intensive studies have been made seeking genetic diversity among various isolated populations of S. infraimmaculata in northern Israel at the southernmost edge of their distribution [2] 


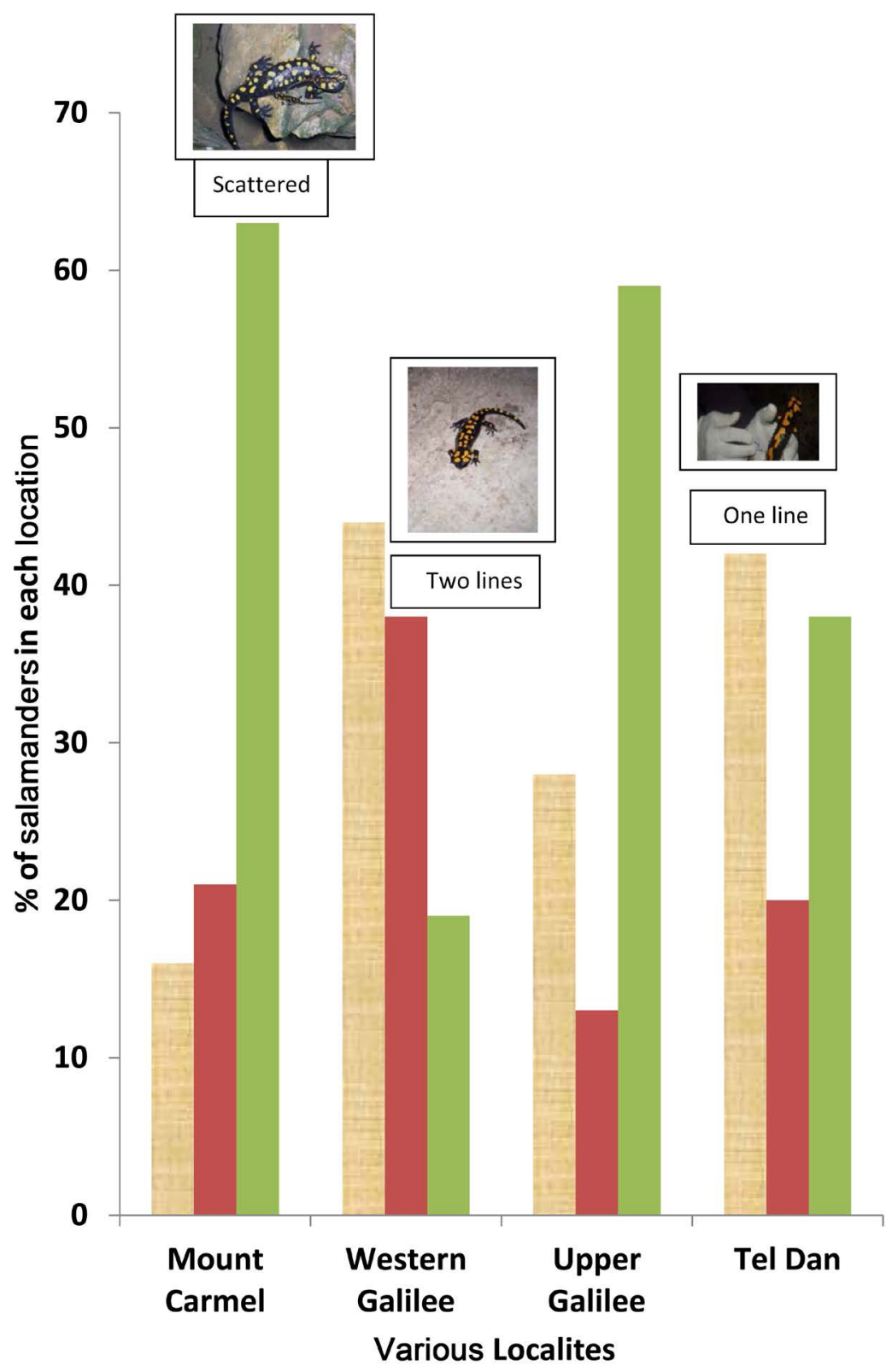

Figure 4. Spots arrangements on dorsal sides of Salamandra infraimmaculata from various areas.

[5] [14] [15] [24] [25]. Different methods have been used to compare the genetic variations in various areas and in isolated populations. Samples were taken mainly during the larvae stages at the breeding places (Figure 1). No variation was found among the three different areas comparing blood plasma proteins [24], or in the 10 enzyme systems with 14 loci [20]. However, using different molecular methods, there is strong support of our hypothesis that a variation exists on a genetic level among the methods used (Figure 7). An analysis using various primers with RAPD amplification methods found differences between the different populations in various areas, however, it is very difficult to separate between areas and habitats due to the fact that these methods are not consistent and depend on the primers [26]. On the other hand, using mitochondrial 


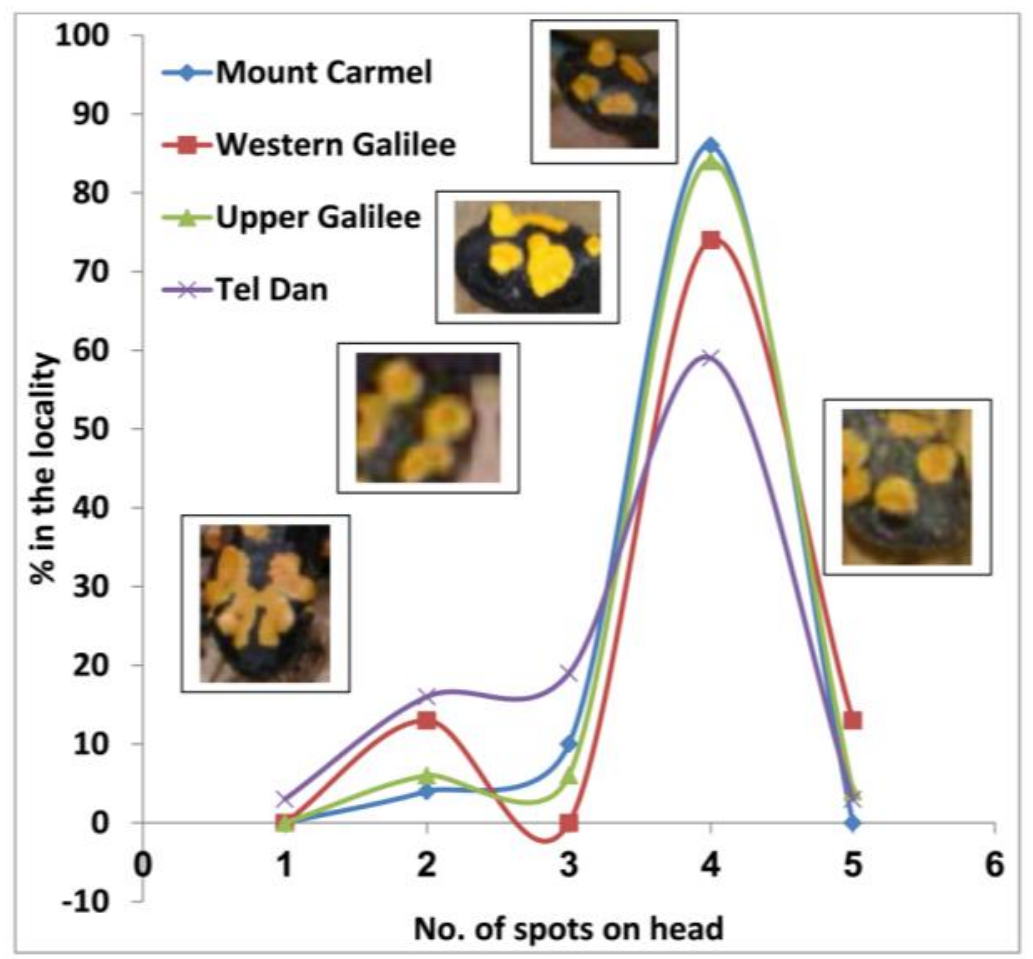

Figure 5. Spots arrangements on heads of Salamandra infraimmaculata from various areas.

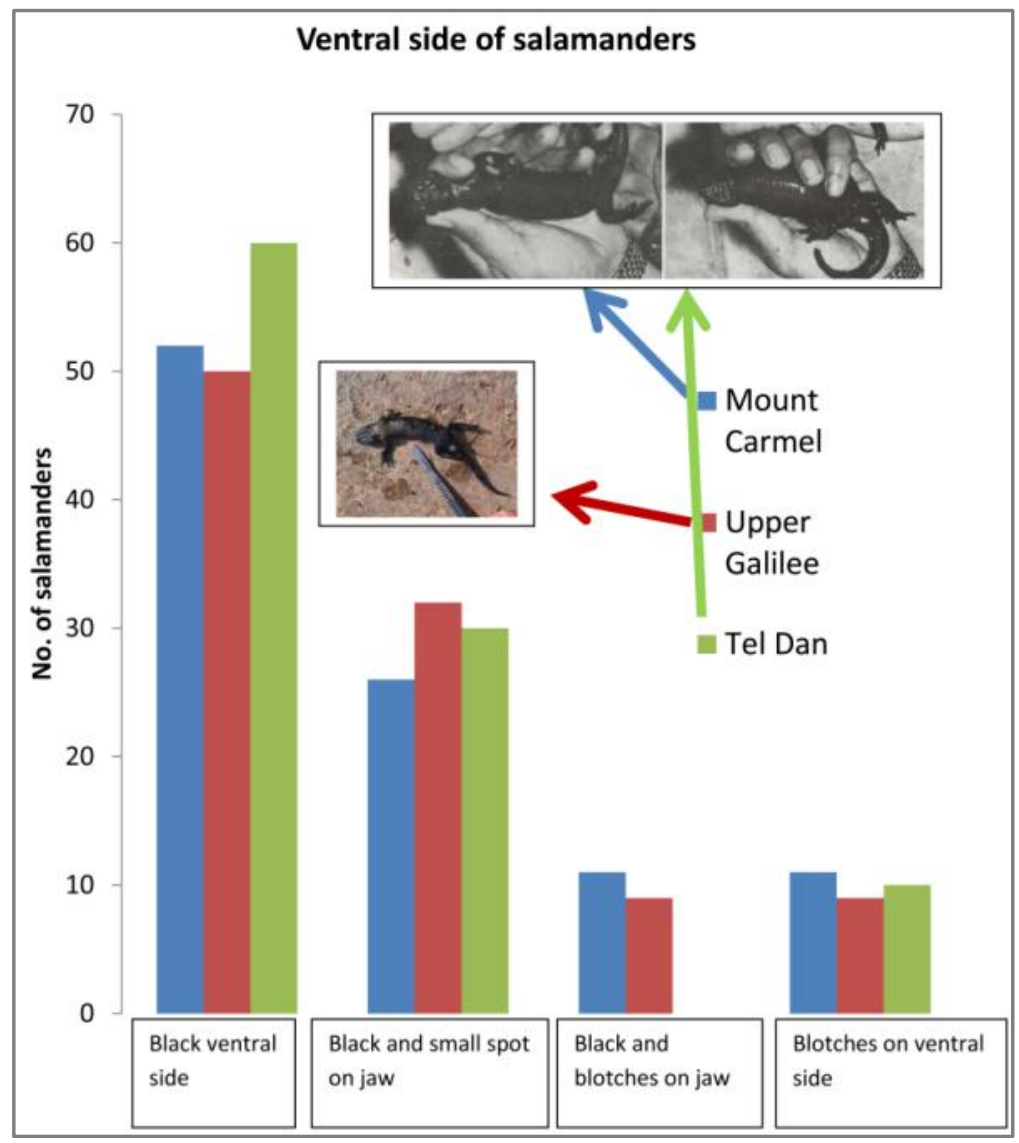

Figure 6. Ventral side of Salamandra infraimmaculata from various areas. 


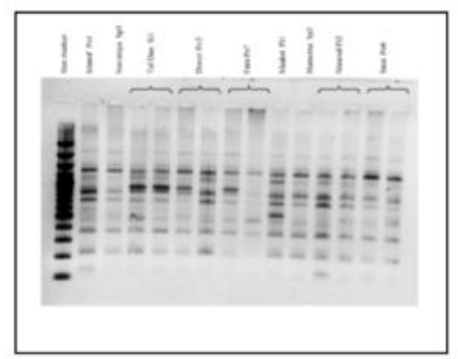

An example of a RAPD-PCR band pattern obtained using the OPA11 primer. Only the larvae found to be different are represented.

(Goldberg, Nevo, and Degani, 2011)

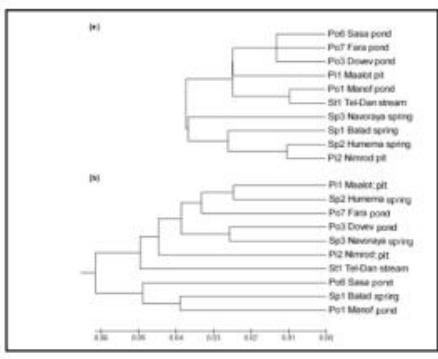

Phylogenetic tree of $S$.

infraimmaculata based on the

Random Amplification of

Polymorphic DNA (RAPD)

method of 17 loci (Tamura, K. et al. 2011).

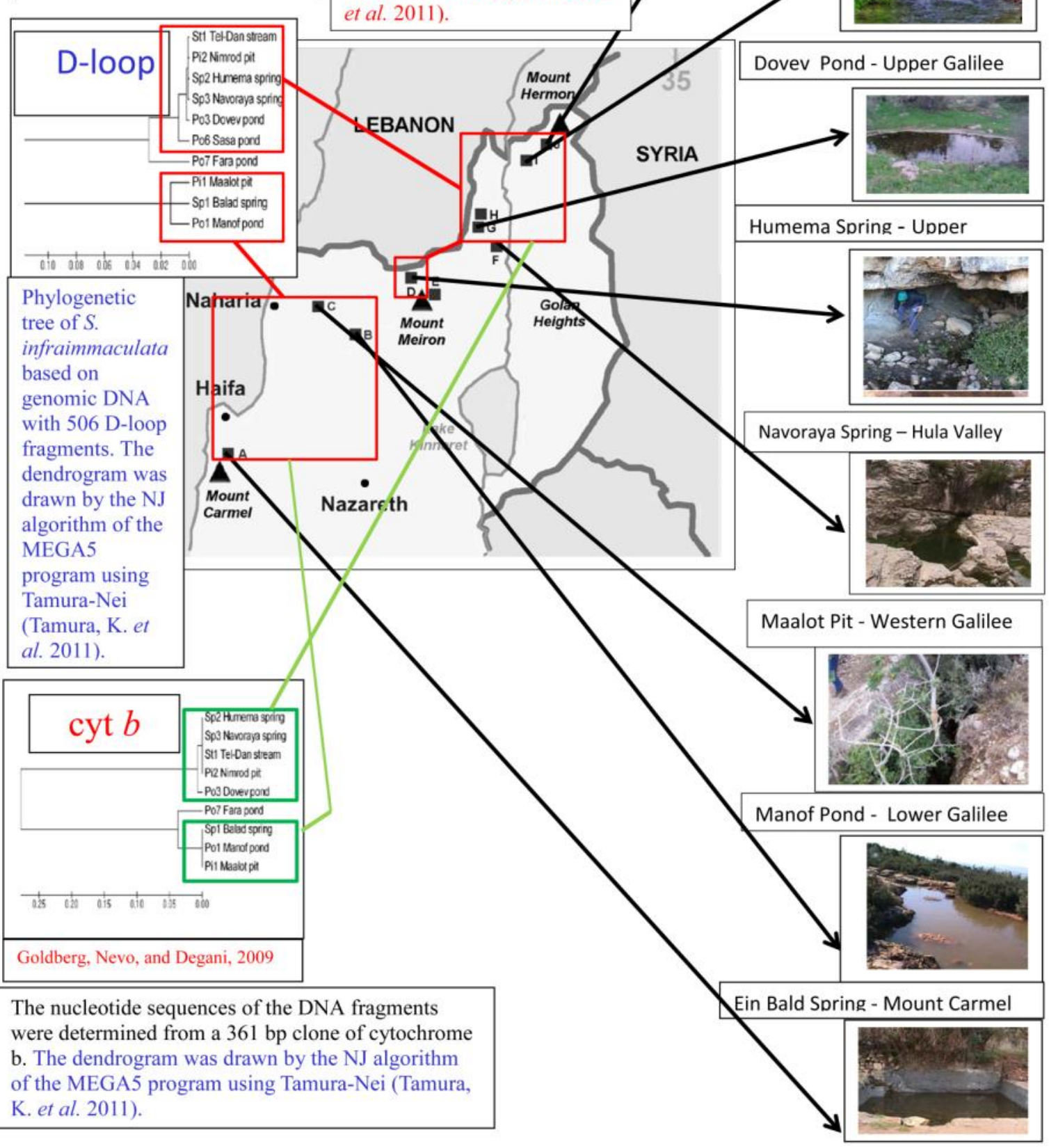

Figure 7. Salamandra infraimmaculata species-RAPD-PCR, nucleotide similarity and divergence of Cyt $b$ and D-loop fragment sequences from different areas in Israel. 
cytochrome b fragment and D-loop regions DNA (GenBank accession nos. EU 852723EU 852738) [14] [15], differences were found between populations in various localities in northern Israel (Mount Hermon, Tel Dan, Naftali Mountains, Upper Galilee, Hula Valley, Western Galilee, Lower Galilee and Mount Carmel) (Figure 1 and Figure 7). According to these results, the genetic variations change from north to south: a high genetic variation was found between the northern populations (Mount Hermon, Tel Dan) and the southern populations (Lower Galilee and Mount Carmel) (Figure 7). Different breeding places (springs, rain pools and rock pits) are found in all of the various areas. The genetic differences are not sharp according to breeding place, especially using mitochondrial DNA, rather according to area.

Degani et al. studied the genetic divergence and variation of $S$. infraimmaculata populations using Amplified Fragment Length Polymorphism (AFLP) data. AFLP is a popular technique that uses linkers to combine elements from restriction fragment-length polymorphism (RFLP) and random amplified polymorphic DNA (RAPD) methods to PCR amplify restriction-based molecular markers from random locations in the genome (Figure 8). Using difference analysis methods of AFLP summaries [25], Analyses of Molecular Variance (AMOVA) tests in GenALEx 6.4 were used to examine the distribution of genetic variation at three hierarchical levels: within groups, defined either as subspecies or as the genetic clusters identified in BAPS; among populations; and among regions. A mantel test was used to examine the relationships between populations by distance and genetic diversity, pairwise genetic distances among populations to produce matrices of genetic distances, and the tree of construction as estimated by Nei and Li's distance matrix using Tools for Population Genetic Analyses (TFPGA). The evolutionary history was inferred using the neighbor-joining method. The tree construction of the level of genetic distance was estimated by Nei and Li's distance matrix with phylogenetic analyses using MEGA5 software. All of the literature sources on AFLP analysis are mentioned in [25].

The results of AFLP methods using $S$. infraimmaculata larvae from different areas collected at breeding sites, a total of 479 polymorphic amplicons (bands), were generated from four combinations of AFLP selective primers from 93 individuals. Individual clustering analysis by BAPS divided individuals into genetic clusters. The fractional membership of each individual to genetic cluster is illustrated in Figure 8. Cluster 5, which represented only the St 1 population, is located on a separate branch of the dendrogram and differs from all the other clusters [25]. Clusters 1, 2 and 4 included 10 individuals (9.3\%) from four populations and was represented at the southern area of $S$. infraimmaculata distribution (Mount Carmel and Lower Galilee Western Galilee) (Figure 8). Cluster 2 included 12 individuals (12.9\%) from seven populations and was represented in all the sub-regions and at all types of breeding sites. Cluster 3 represented most of the populations from Western Galilee to Mount Hermon in northern Israel. Cluster 3, the most common of almost all of the populations, included 44 individuals from seven populations (47.3\%) and was found in all different breeding types of salamander larvae, but was absent in the two southern populations. Cluster 4 included 26 individuals $(28.0 \%)$ from six populations from all of the areas studied in all types of breeding sites except for rock pool holes. Using DNA extract and microsatellite analysis, 


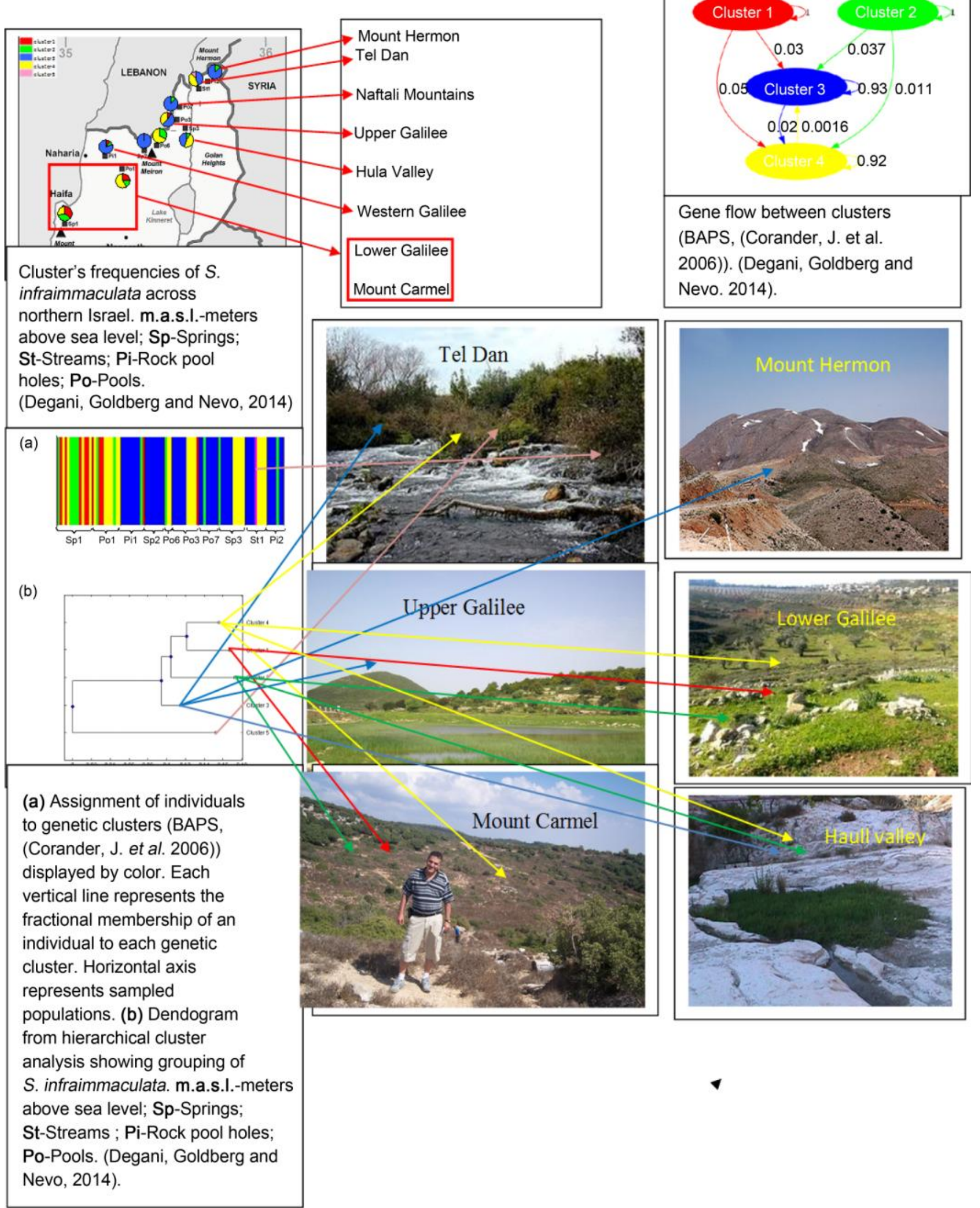

Figure 8. Cluster frequencies of $S$. infraimmaculata across Israel defined by AFLP data analysis (BAPS, Coranr, J., et al., 2006). 
Blank [7] found two major sub-population variations between Mount Carmel and Galilee (Lower Galilee). These methods seem to be more sensitive than AFLP. In summary, the results of AFLP were again similar to what was found in mitochondrial DNA, whereby the genetic variations change from north to south. High genetic variation was found in the northern (Mount Hermon, Tel Dan) and southern (Lower Galilee and Mount Carmel) populations, and not according to breeding type, spring or ponds that were found in most of the areas.

\section{The Life Cycle of S. infraimmaculata}

Different stages of $S$. infraimmaculata have been described in many papers and are shown in Figure 9. The terrestrial life of $S$. infraimmaculata is described less than the larvae stages at the southern border of its distribution. Salamanders at the southern limit of their distribution are active mainly in the winter (Figure 10). Activity is mostly local, and such activity can also be found in summer. This local activity was studied mainly in the Galilee [9]. On hot days, the salamanders are found in hiding places, holes and caves in the ground [2]. Migration to breeding places is limited to the hill populations, since the specific environmental conditions at Tel Dan greatly reduce the need for this [10]. Activity takes place under conditions of $0^{\circ} \mathrm{C}-20^{\circ} \mathrm{C}$ and $60 \%-100 \%$ $\mathrm{RH}$. Most of the salamanders from Upper Galilee are active at temperatures between $5^{\circ} \mathrm{C}$ and $9^{\circ} \mathrm{C}$, and in Tel Dan between $9^{\circ} \mathrm{C}$ and $11^{\circ} \mathrm{C}$ (Figure 11). However, no difference

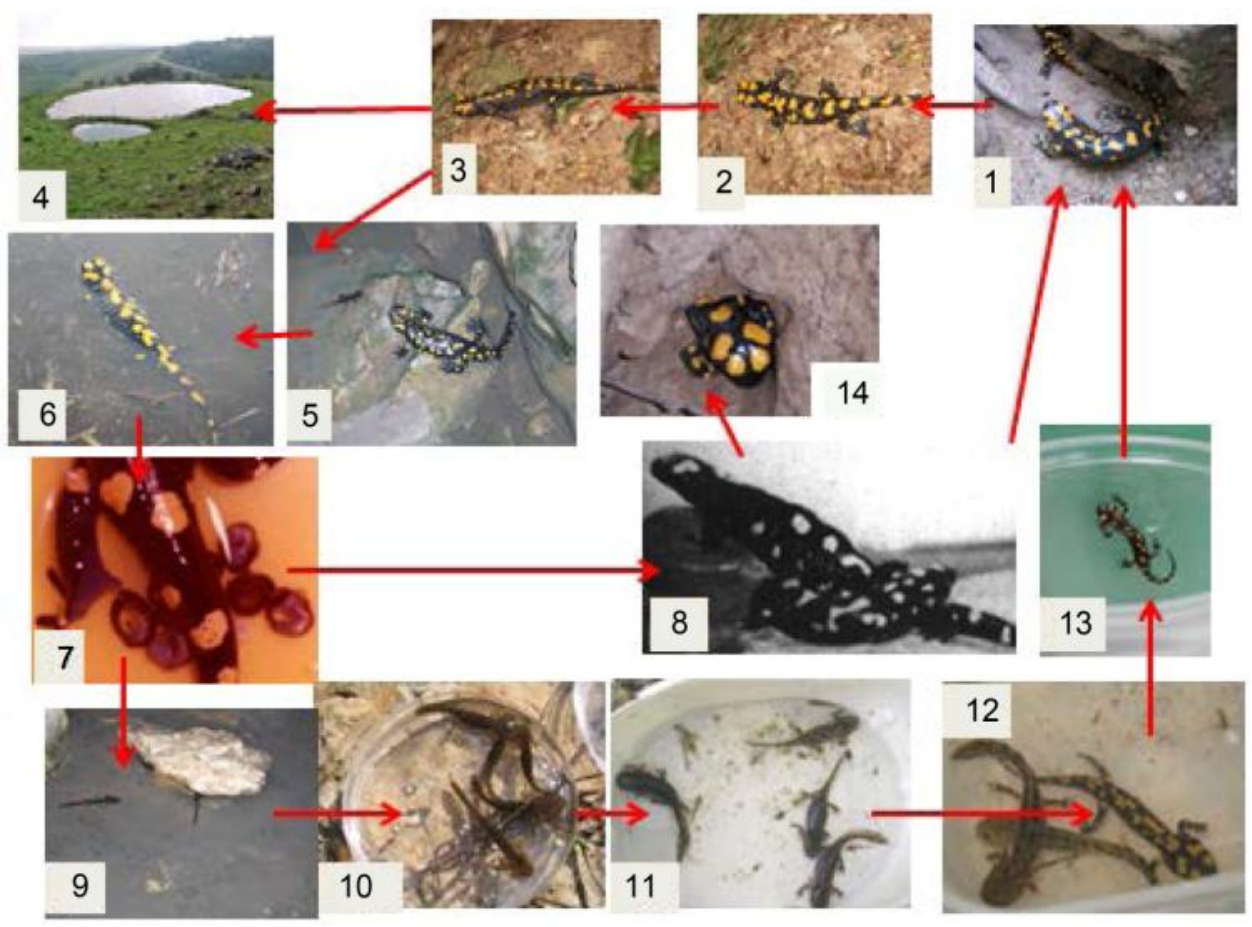

Figure 9. Life cycle of Salamandra infraimmaculata along the southern border of its distribution: 1-salamanders in terrestrial habitats; 2 and 3-salamanders migrating to breeding places; 4-winter ponds in breeding places; 5 -female salamanders reaching the breeding place; 6 and 7-salamander oviposition; 8-sexual behavior and mating of salamanders; 9, 10 and 11-larvae of salamanders; 12-salamanders undergoing metamorphosis; 13-juvenile salamanders moving from breeding places to terrestrial life; 14-adult salamanders in a hole in the ground that serves as a hiding place. 


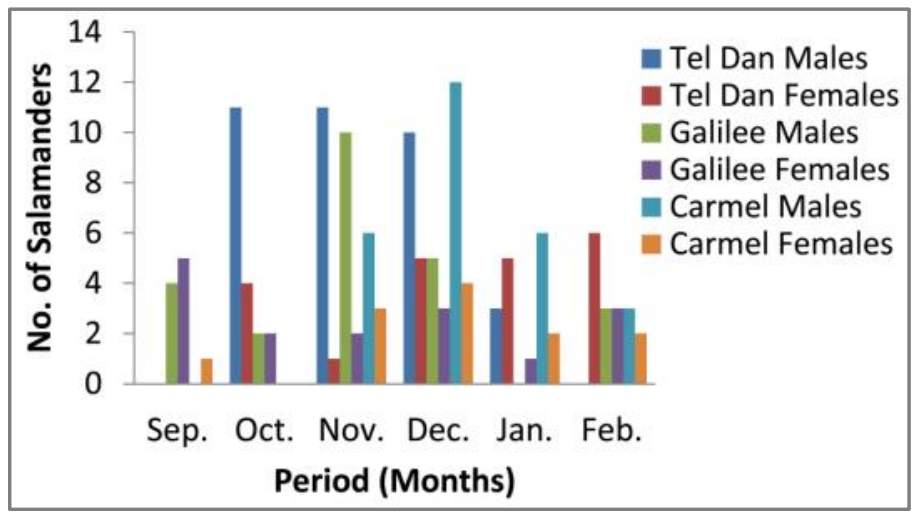

Figure 10. Comparison between activities of Salamandra infraimmaculata in various areas, 1978-1979.

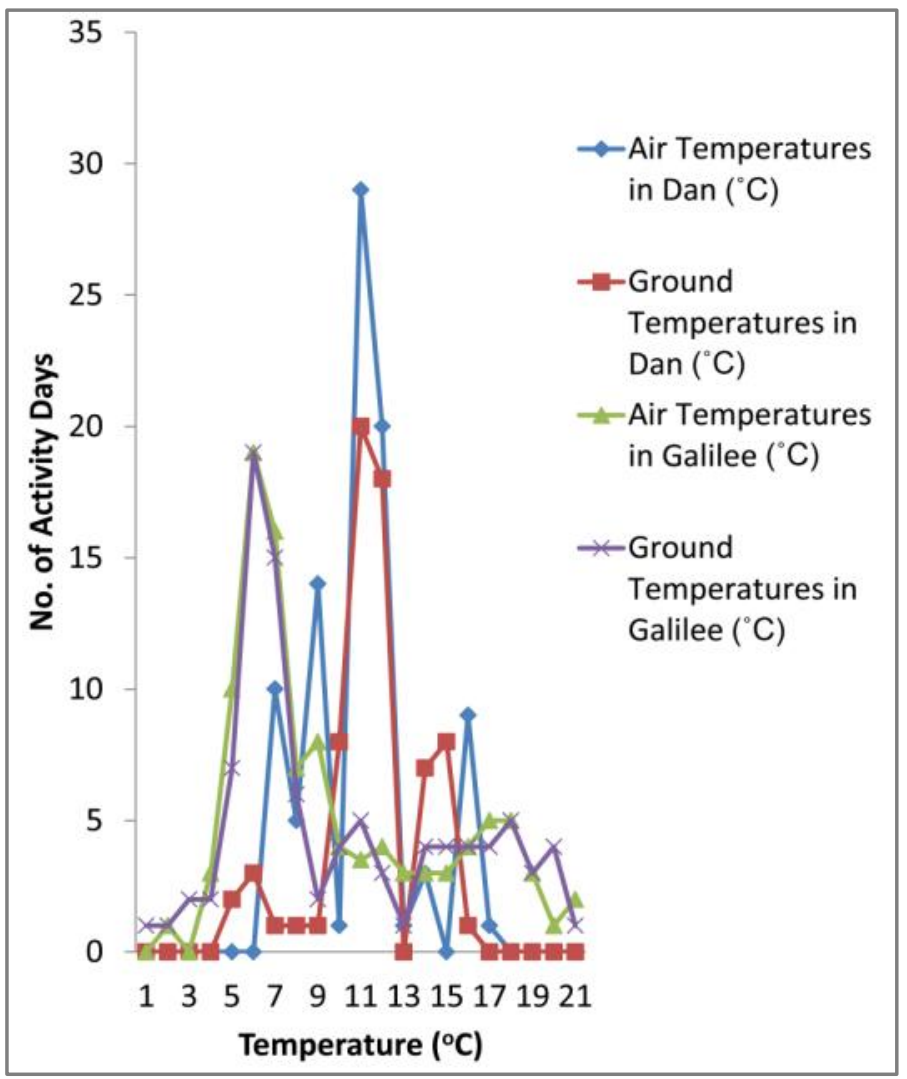

Figure 11. The activity of salamanders as a function of temperature in two different areas, Upper Galilee and Tel Dan.

was found between populations for activity under various levels of relative air humidity (Figure 12): most activities during day occur at $90 \%$ and $100 \%$ high humidity levels, which help prevent dehydration of the salamanders during migration to the breeding places. The high activity is found during breeding periods from October to December (Figure 10), and males are more activity than females. Population size was related directly to habitat type [9] [10]. The density in Tel Dan adult's population is higher than in the Galilee and changes according to conditions in the habitats [10]. The $S$. infraimmaculata is ovoviviparity (Figure 9), and the larvae are born alive in single and small 


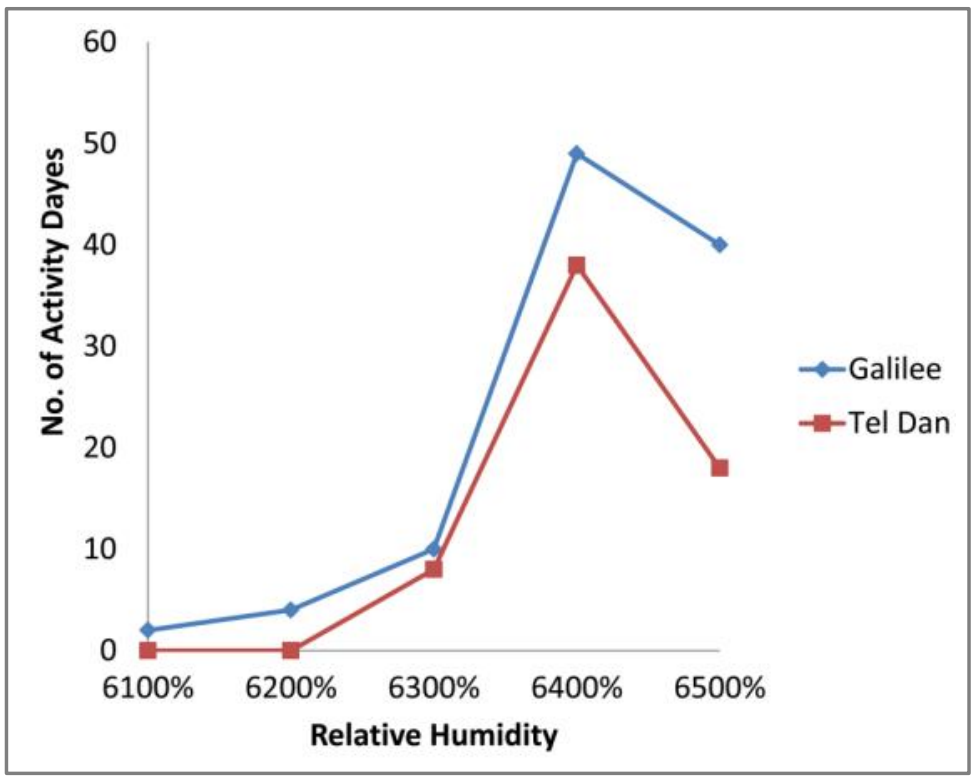

Figure 12. The activity of salamanders as a function of relative humidity in two different areas, Upper Galilee and Tel Dan.

batches, generally wrapped in their embryonic membrane. Sexual behavior occurs mostly after the oviposition of the larvae at the breeding places and is described for the Upper Galilee population [2]. The description of sexual behavior of $\mathcal{S}$. infraimmaculata is presented in Figure 13. The salamanders after mating are solitary and find hiding places to prevent dehydration [18]. At the time that the larvae were born, the weights are $0.2-0.4 \mathrm{~g}$, but they vary in different areas and habitats [18]. There are no significant differences between larvae size in the three different areas: Tel Dan, Upper Galilee and Mount Carmel (Figure 14). There is also no difference in growth in the different areas, but there are differences in larvae growth between the various breeding places according to ecological conditions (Figure 15). In streams, as in Tel Dan, or in springs where water temperatures were lower compared to winter pools, the growth rate was lower, and the periods of larvae growth and complete metamorphosis were longer (Figure 15) [2] [14] [15] [16] [24] [27].

\section{Physiological Adaption to Terrestrial Life in Various Habitats}

The survival of the terrestrial phase of Amphibia, which is not the ability to prevent dehydration throughout the skin, is through the ability to retain extended dehydration by accumulating water in the body, a high plasma fluid concentration and low metabolism during activity in hiding places in the hot, dry season [20] [21]. Most studies on physiological adaption to terrestrial life have been published for Aura, which adapted to more arid environments compared to Urodela [20]. The physiological adaption to terrestrial life of $S$. infraimmaculata was examined by comparing salamanders from two semi-arid environments at the southern border of this species' distribution (Upper Galilee and Mount Carmel) to a moist habitat (Tel Dan) (see Section 2, Different Habitats, in this paper) [18] [24] [27] [28] [29] [30] [31] [32]. The rate of dehydration of mature salamanders from Upper Galilee and Mount Carmel was much lower under the same 


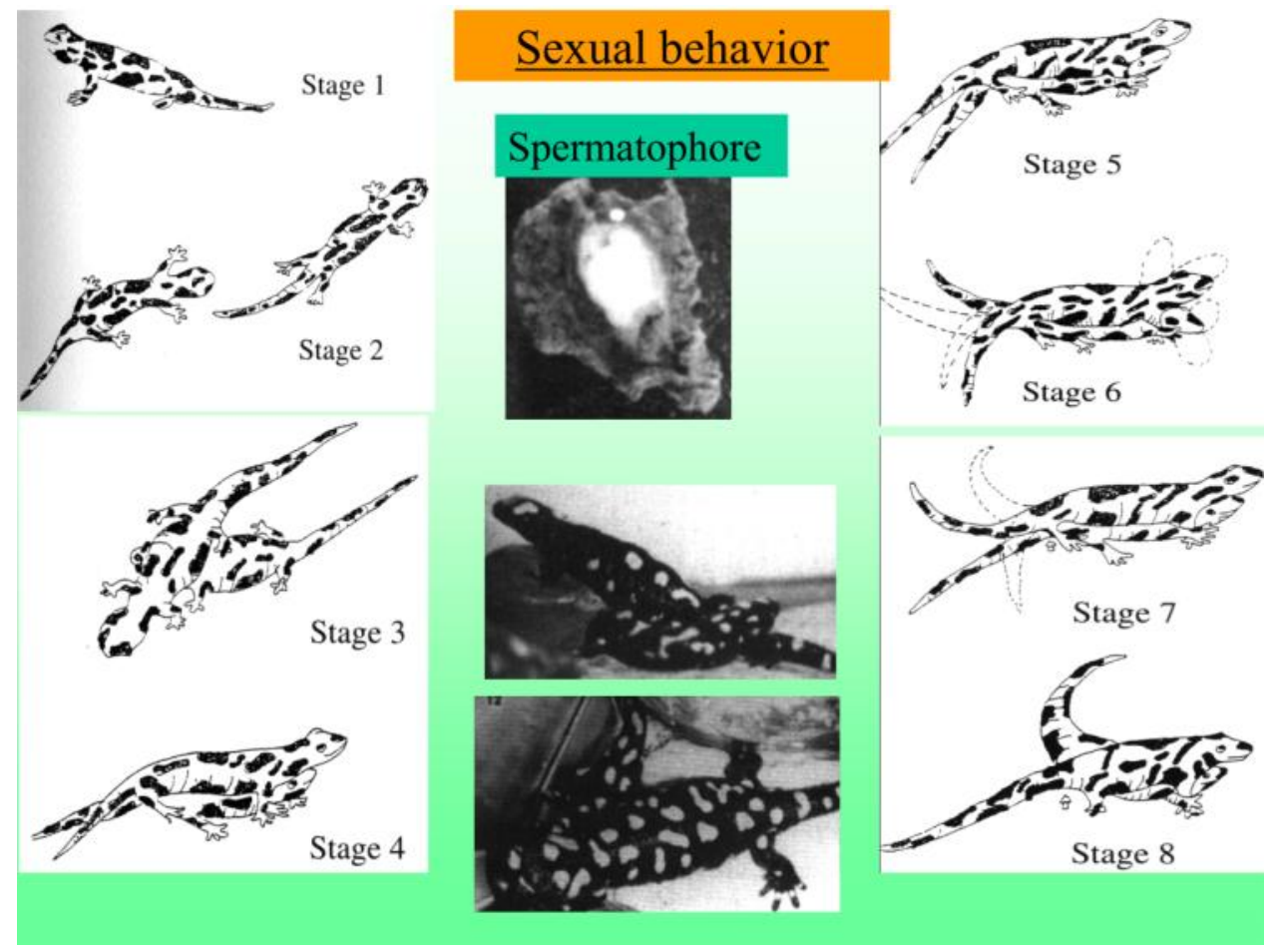

Figure 13. The sexual behavior of Salamandra infraimmaculata (Degani 1978, 1986). Stage 1: The male moves to the breeding place and raises his body on his front limbs while accelerating his breathing rate. He moves and from time to time changes his standing position. Stage 2: The male chases the females that pass next to him. During the activity period, the male and female are observed moving together. Stage 3: The female is ready for mating, she stops moving, stands and allows the male to penetrate under her body. Stage 4: The male pushes his body below the female and reaches the top of the female while she is straddling him. Stage 5: The amplexus. The female grasps the male with her front limbs, and he raises his front limbs to the sides. Stage 6: The male is under the female and moves his head and tail from side to side, rubbing the ventral epidermis of the female's jaw. The female also moves her head reciprocally in the opposite direction of the male with her head and tail. Stage 7: The male stops his movements and secretes the spermatophore to the ground. The base of the spermatophore is elliptical, measuring some $8 \times 6 \mathrm{~mm}$ in diameter, with a height of $8 \mathrm{~mm}$. It is transparent, with white pots on the upper part. The movements of the female continue, especially as regards the tail and cloacal region. Stage 8: The male turns his body at $60^{\circ}-90^{\circ}$ to that of the female. Stage 9: The female continues the movement of the lower part of the body and tail, makes contact with the upper part of the spermatophore, and continues hermovement until penetrating the entrance to the cloaca. Her movement then ceases and the spermatophore is drawn into the body. Stage 10: Amplexus ceases and the couple parts. This process may be repeated more than once.

conditions [30] than salamanders from Tel Dan (Figure 16(A)), and the water loss limit survival of salamanders from Tel Dan was eight days compared to salamanders from Upper Galilee and Mount Carmel, which was 15 days [30]. This adaption to terrestrial life might help salamanders to survive longer in semi-arid habitats compared to moist habitats under extreme conditions where $\mathcal{S}$. infraimmaculata are found. During dehydration, the plasma concentration of salamanders increases mainly by urea, $\mathrm{Na}^{+}$and $\mathrm{CL}$ (Figure 16(B)). S. infraimmaculata from semi-arid habitats (Upper Galilee and Mount Carmel) survive at a high plasma concentration compared to salamanders from moist habitats (Tel Dan) [29] [30]. S. infraimmaculata are active under very specific conditions 

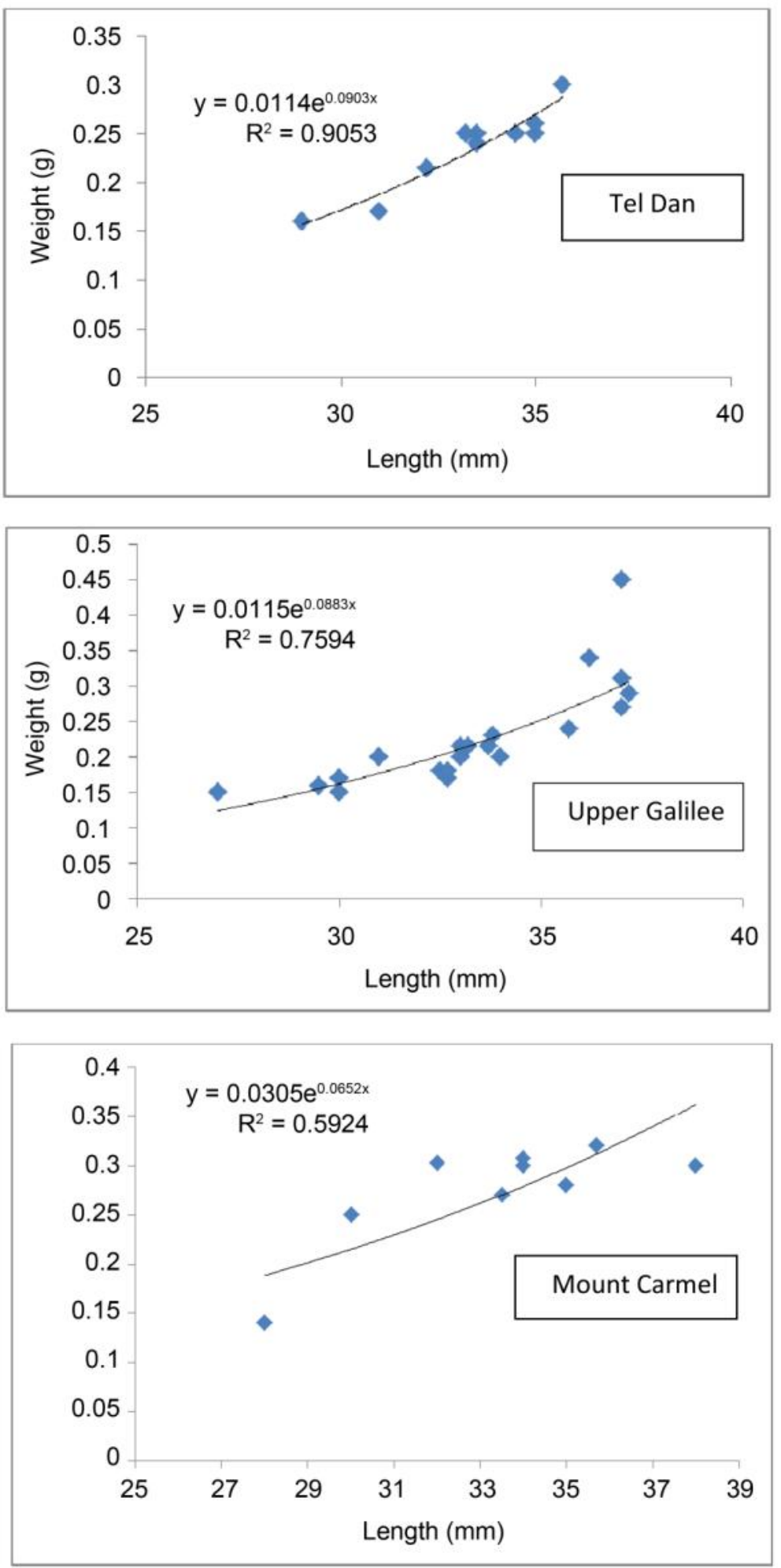

Figure 14. Weight as a function of length in newborn larvae at various localities, Tel Dan, Upper Galilee and Mount Carmel.

(see Section 5). These conditions are found in moist habitats compared to semi-arid habitats in particular at summer time during the hot, dry season. Low metabolism [31], as was found in salamanders from semi-arid habitats compared to moist habitats 

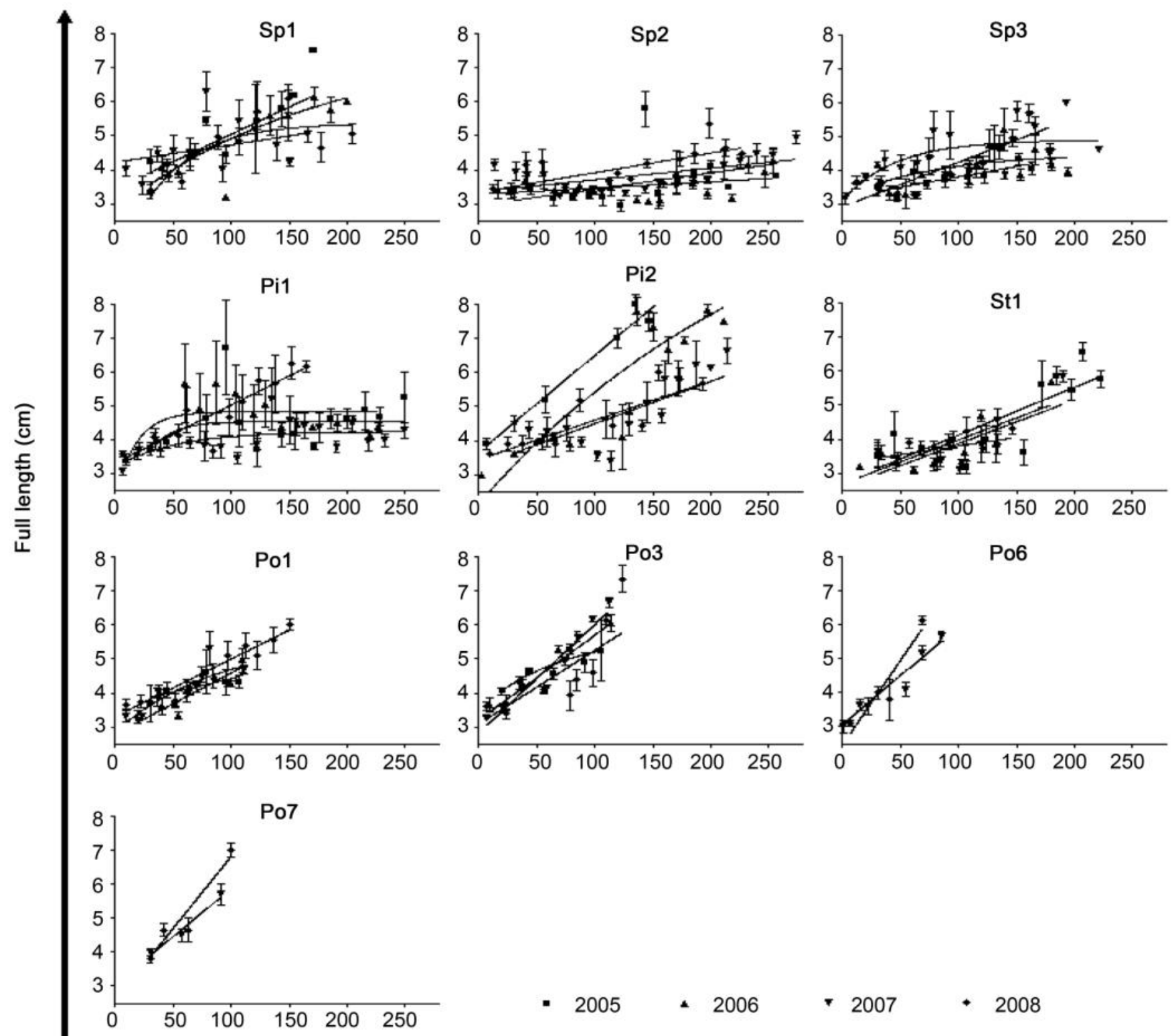

$$
\text { - } 2005+2006+2007+2008
$$

Days

Figure 15. Stream: St1-Tel Dan Springs: Sp1-Balad, Sp2-Humema and Sp3-Navoraya. Pools: Po1-Manof, Po3-Dovev, Po5Lehavot, Po6-Sasa, Po7-Fara. Rock pool holes (pits): Pi1-Maalot and Pi2—Nimrod.

(Figure 17), gives the advantage of surviving longer periods in hiding places without feeding and activity. The temperatures of $\mathcal{S}$. infraimmaculata from three different areas were studied by comparing the critical thermal maxima (CTM) [27] from different areas. It was found that the CTM was significantly higher in the larvae and metamorphosis of salamanders from both Upper Galilee and Mount Carmel (semi-arid habitats) compared to those from the Tel Dan area (moist habitat) (Figure 18).

\section{Discussion}

The ecological adaption of species in natural habitats refers to the study of natural 

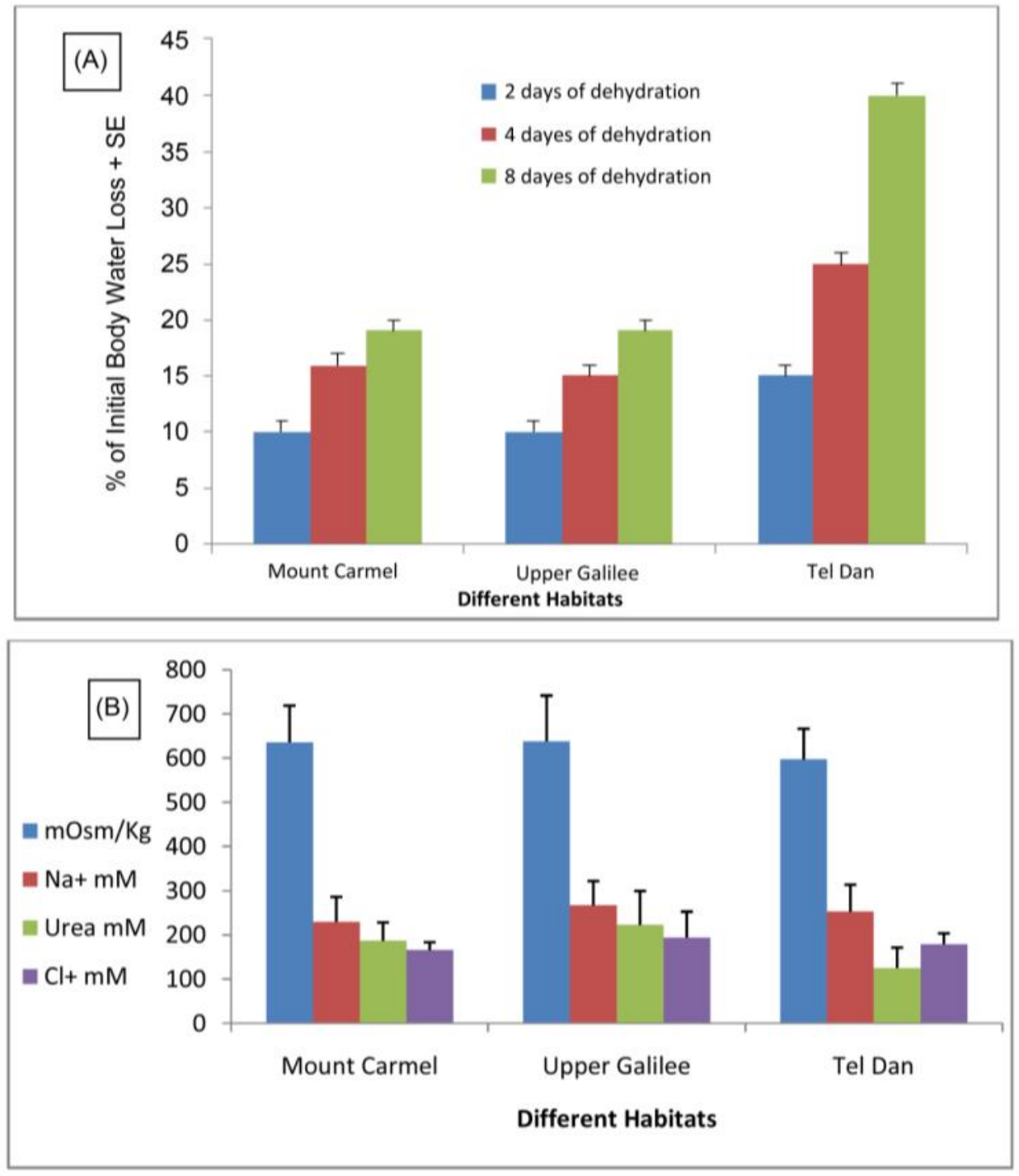

Figure 16. (A) Water loss at $5 \%$ relative humidity $(\mathrm{RH})$ and $25^{\circ} \mathrm{C}$ (mean $+\mathrm{SE}$ ). (B) Plasma concentration and composition of salamanders maintained on soil at room temperatures $\left(25^{\circ} \mathrm{C} \pm 5^{\circ} \mathrm{C}\right)($ mean $+\mathrm{SE})$.

systems, emphasizing interdependence in ecological systems on other elements and characterizing the animal. In the present paper, we will consider the relatively many different characteristics from different fields of biology of $S$. infraimmaculata regarding adaptation to semi-arid environments in relatively extreme conditions by comparing these characteristics to moist habitats. The suggested model (Figure 19) is based on more than 40 papers (cited above) and unpublished data showing that different fields of biology are involved in the ecological adaption ability of this species in extreme conditions. There not only connections between the ecological and biological adaption of the different parameters, but various biological parameters also interact with one another. The largest body size [24] of salamanders from semi-arid areas is affected by all the other biological parameters and ecological adaption to semi-arid environments. For example, the ecological adaption helped salamanders reduce their rate of dehydration [30], long movement distances [10] [22], a large number of larvae per batch [18], 


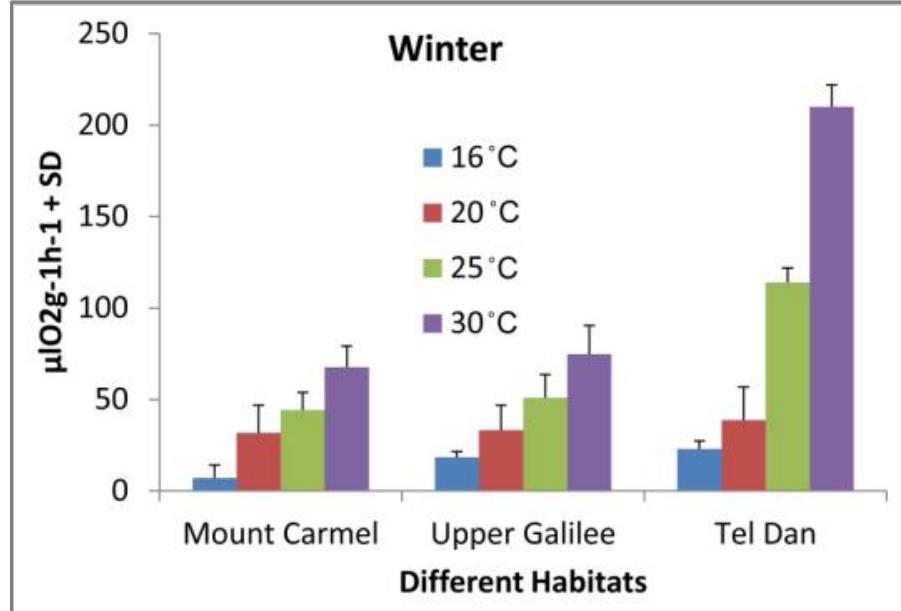

\section{Summer}

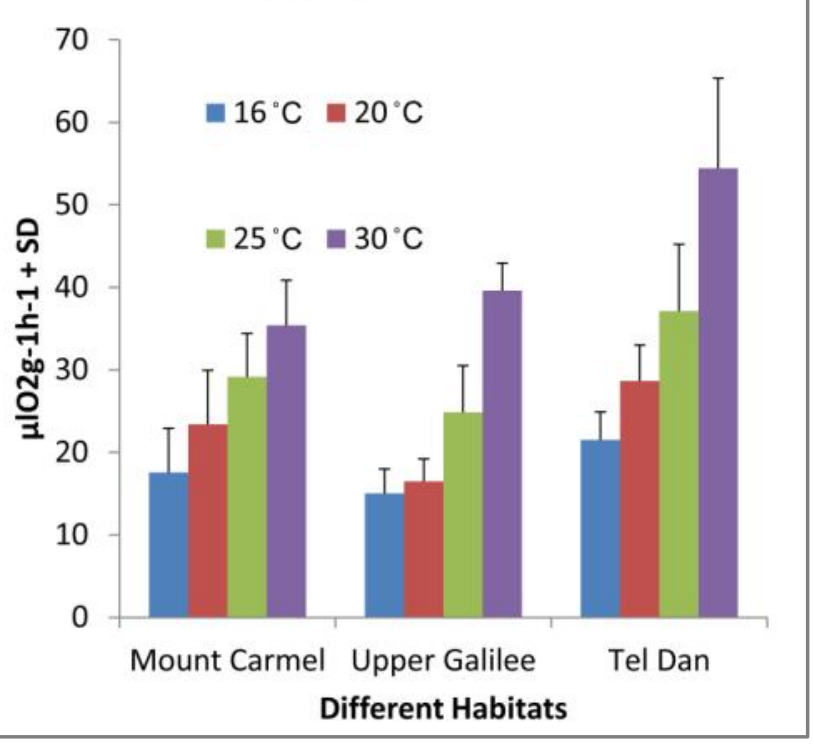

Figure 17. Metabolism (oxygen consumption per gram body weight) of salamanders from different areas.

low metabolism and less energy lost during dry periods [31]. On the other hand, the physiological adaption to xeric habitats helped salamanders survive in these habitats and complete the life cycle in the various areas (Figure 9). Other very important conclusions that were found by examining the interaction between all the various ecological and biological parameters are that the adaption is more strongly affected by semi-arid environments in the terrestrial phase and not in the aquatic phase. In all the various areas where $S$. infraimmaculata habitats are found, there are different breeding places, streams, springs, rock pools and winter pools where larvae of this species are located (Figure 1, Figure 2) [14] [15] [16]. However, the ecological conditions in these aquatic places differ. Therefore, the growth rate and complete metamorphosis of salamander larvae are not according to area but to type of breeding place, which is affected by the ecological conditions at each specific breeding place (Figure 15). On the other hand, the physiological adaptation of terrestrial life differs among $S$. infraimmaculata from various areas (Figure 16) [29] [30] [32]. In semi-arid areas, the terrestrial phase 


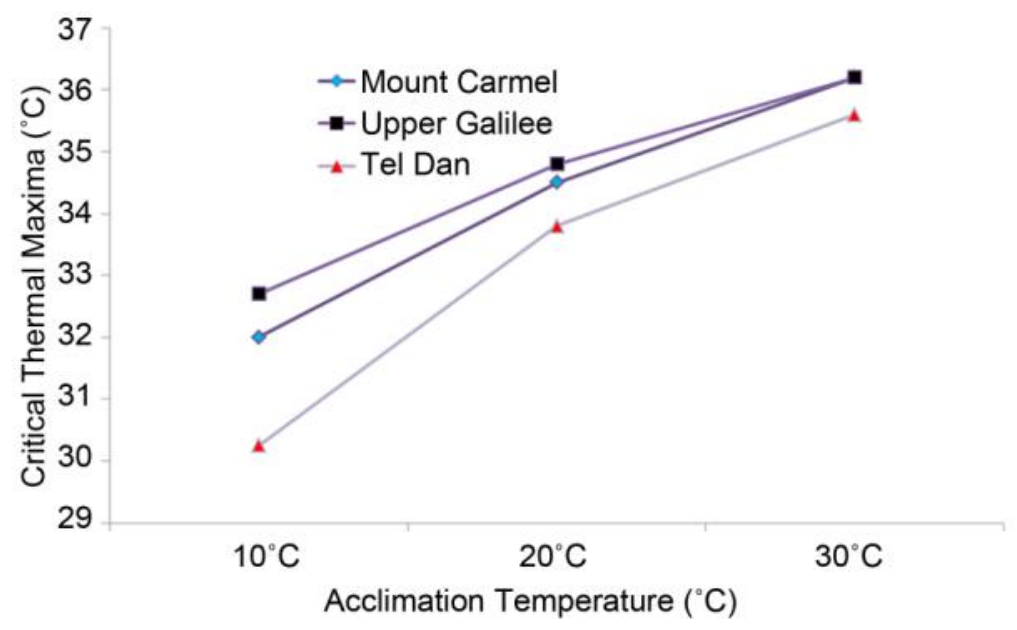

Figure 18. Critical thermal maxima (CTM) of adult $S$. infraimmaculata from Upper Galilee and Mount Carmel (semi-arid habitats) and the Tel Dan area (moist habitat).

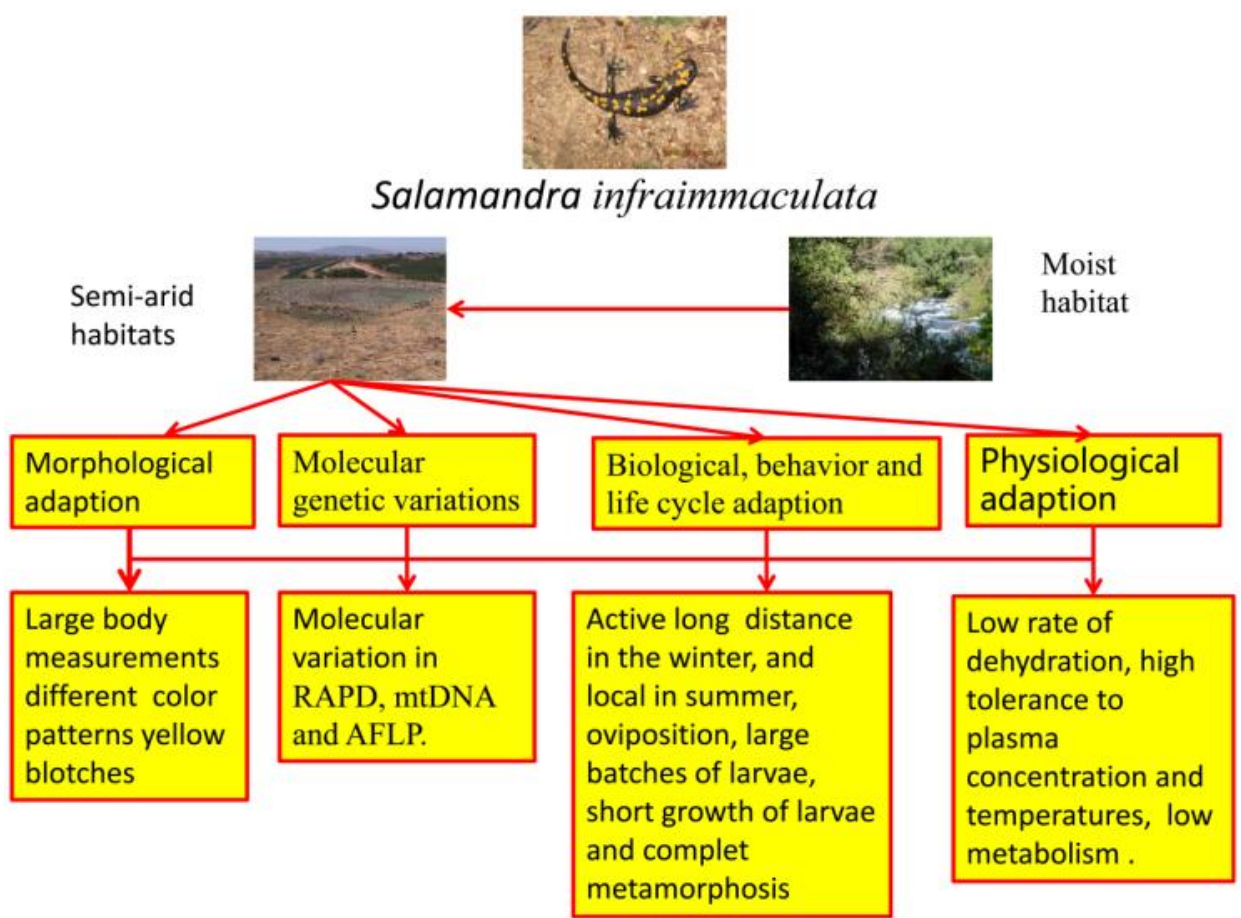

Figure 19. Model of different curatrixes showing the adaption of $S$. infraimmaculata to semi-arid conditions compared to moist conditions.

is under significantly greater danger of dry conditions compared to moist habitats following metamorphosis in the terrestrial phase. In many important parameters that were studied, as summarized in the model (Figure 19), there are variations among the different populations and metapopulations. The study on genetic variation among populations supports the hypothesis that the terrestrial phase might be affected by environment selections. The genetic variation among moist habitats (Tel Dan) is greater than other populations in semi-arid habitats (Upper Galilee and Mount Carmel) [5] [6] [14] [15] [25] [26]. 


\section{Conclusion}

In summary, the proposed model in this paper (Figure 19) showed that in order to understand the heterogeneity adaption among $S$. infraimmaculata populations in northern Israel's southern border of its distribution, different parameters of different biological and ecological aspects must be examined. This model's adaptation to semi-arid environments was based on the results of morphology, behavior, life cycle and physiology, which might be explained by genetic differences between various habitats, specifically between moist and xeric.

\section{References}

[1] Weisrock, D.W., Papenfuss, T.J., Macey, J.R., Litvinchuk, S.N., Polymeni, R., Ugurtas, I.H., Zhao, E., Jowkar, H. and Larson, A. (2006) A Molecular Assessment of Phylogenetic Relationships and Lineage Accumulation Rates within the Family Salamandridae (Amphibia, Caudata). Molecular Phylogenetics and Evolution, 41, 368-383.

https://doi.org/10.1016/j.ympev.2006.05.008

[2] Degani, G. (1996) The Salamander at the Southern Limit of Its Distribution. Laser Pages Publishing, Israel.

[3] Steinfartz, S., Veith, M. and Tautz, D. (2000) Mitochondrial Sequence Analysis of Salamandra Taxa Suggests Old Splits of Major Lineages and Postglacial Recolonizations of Central Europe from Distinct Source Populations of Salamandra salamandra. Molecular Ecology, 9, 397-410. https://doi.org/10.1046/j.1365-294x.2000.00870.x

[4] Escoriza, D., Comas, M.M., Donaire, D. and Carranza, S. (2006) Rediscovery of Salamandra algira Bedriaga, 1833 from the Beni Snassen Massif (Morocco) and Phylogenetic Relationships of North African Salamandra. Amphibia-Reptilia, 27, 448-455. https://doi.org/10.1163/156853806778190042

[5] Degani, G. and Kaplan, D. (1999) Distribution of Amphibian Larvae in Israeli Habitats with Changeable Water Availability. Hydrobiologia, 405, 49-56.

https://doi.org/10.1023/A:1003796820900

[6] Blank, L., Sinai, I., Bar-David, S., Peleg, N., Segev, O., Sadeh, A., Kopelman, N., Templeton, A., Merila, J. and Blaustein, L. (2013) Genetic Population Structure of the Endangered Fire Salamander (Salamandra Infraimmaculata) at the Southernmost Extreme of Its Distribution. Animal Conservation, 16, 412-421. https://doi.org/10.1111/acv.12009

[7] Olgun, K., Avcý, A., Emin Bozkurt, E., Üzüm, N., Mehmet Tural, M. and Mert Fýrat Olgun, F. (2015) Range Extensions of Two Salamanders [Neurergus Strauchii (Steindachner, 1887) and Salamandra infraimmaculata Martens, 1885] (Caudata: Salamandridae) from Anatolia, Turkey. Russian Journal of Herpetology, 22, 289-296.

[8] Bogaerts, S., Sparreboom, M., Pasmans, F., Aroub Almasri, A., Wouter Beukema, W., Shehab., A. and Amr, Z.S. (2013) Distribution, Ecology and Conservation of Ommatotriton Vittatus and Salamandra infraimmaculata in Syria. Salamndra, 49, 87-96.

[9] Degani, G. and Mendelssohn, H. (1978) The Food of Salamandra salamandra (L.) Tadpoles in Israel in Different Habitats. Israel Journal of Ecology, C19-C45.

[10] Degani, G. and Mendelssohn, H. (1982) Seasonal Activity of Salamandra salamandra (L.) (Amphibia, Urodela) in Headwaters of the Jordan River. Israel Journal of Zoology, 31, 77-85.

[11] Sharon, R., Degani, G. and Warburg, M.R. (1996) Environmental Effects on Reproduction in Salamandra salamandra infraimmaculata in North Israel. In: Steinberger, Y., Ed, Preservation of Our World in the Wake of Change, Israel Society of Ecology and Environed Quality Science, Jerusalem, 527-529. 
[12] Sharon, R., Degani, G. and Warburg, M.R. (1997) Oogenesis and the Ovarian Cycle in Salamandra salamandra infraimmaculata Mertens (Amphibia, Urodela, Salamandridae) in Fringe Areas of the Taxon's Distribution. Journal of Morphology, 231, 149-160. https://doi.org/10.1002/(SICI)1097-4687(199702)231:2<149::AID-JMOR4>3.0.CO;2-9

[13] Degani, G., Sela, E., Hankin, Z., Coran, S., Goldberg, T. and Warburg, M.R. (2007) Movement to Rock Pool Hole Breeding Sites of Salamandra infraimmaculata during Colonization of New Breeding Places in Xeric Habitats. Salamandra, 43, 7-12.

[14] Goldberg, T., Eviatar, E. and Degani, G. (2009) Breeding Site Selection According to Suitability for Amphibian Larval Growth under Various Ecological Conditions in the Semi-Arid Zone of Northern Israe. Ecologia Mediterranea, 35, 65-74.

[15] Goldberg, T., Eviatar, E. and Degani, G. (2009) Sequence Analysis of Mitochondrial DNA in Salamandra infraimmaculata Larvae from Populations in Northern Israel. South American Journal of Herpetology, 4, 268-274. https://doi.org/10.2994/057.004.0310

[16] Goldberg, T., Nevo, E. and Degani, G. (2012) Amphibian Larval in Various Water Bodies in the Semi-Arid Zone. Zoological Studies, 51, 345-361.

[17] Degani, G. and Goldberg, T. (2015) Effect of Human Activity in Creating a Death Trap for Salamandra infraimmaculata Seeking Breeding Places during Colonization of New Breeding Sites. American Open Animal Science Journal, 2, 1-11. http://rekpub.com/Journals.php

[18] Degani, G. and Warburg, M. (1995) Variation in Brood Size and Birth Rates of Salamandra salamandra (L.) (Amphibia, Urodela) from Different Habitats in Northern Israel. Amphibia-Reptilia, 16, 341-349. https://doi.org/10.1163/156853895X00424

[19] Sharon, R., Degani, G. and Warburg, M.R. (2000) Ovarian Cycle Pattern of Female Salamndra Salamndra Inframmaculata in Two Habitats in Northern Israel. Journal of Herpetology, 34, 463-465. https://doi.org/10.2307/1565372

[20] Veith, M., Degani, G. and Seitz, A. (1992) High Genetic Homogeneity of Salamandra salamandra (L.) in Israel. Zoologischer Anzeiger, 229, 63-72.

[21] Warburg, M.R. (2007) Longevity in Salamandra infraimmaculata from Israel with a Partial Review of Life Expectancy in Urodeles. Salamandra, 43, 21-34.

[22] Bar-David, S.O., Segev, N., Peleg, N., Hill, A.R., Templeton, C., Schultz, B. and Blaustein, L. (2007) Long Distance Movements by Fire Salamanders (Salamandra salamandra infraimmaculata) and Implications for Habitat Fragmentation. Israel Journal of Ecology and EVolution, 53, 179-196. https://doi.org/10.1080/15659801.2007.10639579

[23] Eiselt, J. (1958) Der feuersalamander, Salamandra salamandra ge zubreit (L.) einer taxonomischen synthese. Abhandlungen und Berichte für Naturkunde und Vorgeschichte, 10, 77154.

[24] Degani, G. (1986) Plasma Protein and Morphology of Salamandra salamandra in Israel. Amphibia-Reptilia, 7, 105-114. https://doi.org/10.1163/156853886X00334

[25] Degani, G., Goldberg, T. and Nevo, E. (2014) Genetic Variation in Salamandra infraimmaculata from Different Habitats Using Amplified Fragment Length Olymorphism. Journal of Biophysical Chemistry, 5, 54-66. https://doi.org/10.4236/jbpc.2014.52007

[26] Goldberg, T., Nevo, E. and Degani, G. (2011) Genetic Diverseness and Different Ecological Conditions in Salamandra infraimmaculata Larvae from Various Breeding Places. Animal Biology Journal, 2, 37-49.

[27] Degani, G. (1982) Temperature Tolerance in Three Populations of Salamanders, Salamandra salamandra (L.). British Journal of Herpetology, 6, 186-187.

[28] Warburg, M.R. (1997) Ecophysiology of Amphibians Inhabiting Xeric Environments. Adaptations of Desert Organisms, Springer, Berlin. https://doi.org/10.1007/978-3-642-60357-0

[29] Degani, G. (1981) Salinity Tolerance and Osmoregulation in Salamandra salamandra (L.) 
from Different Populations. Journal of Comparative Physiology, 145, 133-137. https://doi.org/10.1007/BF00782604

[30] Degani, G. (1981) The Adaptation of Salamandra salamandra (L.) from Different Habitats to Terrestrial life. British Journal of Herpetology, 6, 169-172.

[31] Degani, G. (1983) Oxygen Consumption Rates of Salamandra salamandra (L.) from Different Habitats. British Journal of Herpetology, 6, 281-283.

[32] Degani, G. (1994) Ecophysiology of Salamandra salamandra at the Southern Limit of Its Distribution. Mertensiella, 4, 111-124.

Submit or recommend next manuscript to SCIRP and we will provide best service for you:

Accepting pre-submission inquiries through Email, Facebook, LinkedIn, Twitter, etc. A wide selection of journals (inclusive of 9 subjects, more than 200 journals) Providing 24-hour high-quality service User-friendly online submission system Fair and swift peer-review system Efficient typesetting and proofreading procedure Display of the result of downloads and visits, as well as the number of cited articles Maximum dissemination of your research work

Submit your manuscript at: http://papersubmission.scirp.org/ Or contact ojas@scirp.org 